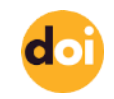

http://doi.org/10.22282/ojrs.2021.80

\title{
INVESTIGATION OF THE INTERACTION ANXIOUSNESS AND PERCEIVED SOCIAL SUPPORT OF THE UNIVERSITY STUDENTS FROM THE DEPARTMENTS GIVING SPORTS EDUCATION IN TERMS OF THEIR SOCIAL NETWORK USAGE AND RELATIONSHIP STATUS
}

Gülen VURAL, Osman GODE, Oğuzhan AVCI, Zehra ÖZDEMİR

\begin{abstract}
The purpose of the current study is to investigate the relationships between the perceived social support, interaction anxiousness, gender, relationship status and purposes for using the social networking sites of the female and male students from the School of Physical Education and Sports in Aydın Adnan Menderes University and the Faculty of Sports Sciences in Muğla Sitk1 Koçman University. The sampling of the study is comprised of a total of 359 students. As the data collection tools, the "Multidimensional Scale of Perceived Social Support" and the "Interaction Anxiousness Scale" were used. In the current study, it was found that the participating students' perception of social support and interaction anxiousness do not vary significantly depending on gender $(\mathrm{p}>0.05)$. While a statistically significant difference was found between the perceived social support of the students having a relationship and that of the students not having ( $>>0.05)$, the relationship status was found to be not leading

to a significant difference in the students' interaction anxiousness. When the students' interaction anxiousness levels were examined, a low and negative correlation was found between the students' perceived social support and interaction anxiousness $(r=-0.278)$. Thus, it can be argued that with increasing perception of social support, the interaction anxiousness level decreases. A statistically significant difference was found between the students' purposes for using social networking sites depending on their gender ( $p>0.05)$. While there is a statistically significant difference based on the students' purposes for using social networking sites in their perceived social support $(\mathrm{p}=0.022 ; \mathrm{p}<0.05)$, there is no such a significant difference in their interaction anxiousness. There is a negative, low and significant correlation between the perceived social support and interaction anxiousness and between the perceived social support and the relationship status ( $\mathrm{r}=-0.278$ and $\mathrm{r}=-0.200$, respectively).
\end{abstract}

\footnotetext{
* It was presented as an oral presentation in the 15 th International Sports Sciences Congress.
}

Key Words: Laser Sailing, Hiking test, Blood Pressure, Heart rate 


\section{INTRODUCTION}

As a social being, it is an indispensable need for human beings to communicate. The rapid changes and developments in information and communication technologies in our century facilitate the life of the individual. The family is the first place where interpersonal communication begins and is experienced most intensely. By narrowing the barriers of communication, it allows individuals to communicate with each other more easily, quickly and interactively. This might lead the individual to a process of change and transformation in his/her social life, social communication and social relationships. One of the novel technologies, Web 2.0 has turned out to be one of the most important technologies making it easier for individuals to communicate and interact with each other with its tools allowing social interaction, cooperation and sharing (3).

In recent social support research, the emphasis has shifted towards the person's own perception of whether social relationships are supportive enough or not; that is, the perceived support (3). Availability of people from whom the person can get support and the personal satisfaction derived from the available support are two important dimensions of social support (10).

Although real-life relationships of individuals from any age group are important for psychological development, it may be difficult for individuals suffering from social anxiety to establish face-to-face relationships.

With the widespread use of the internet, individuals' behaviors of making friends and maintaining friendship relations have been moved to the virtual environment. Social networking sites (Facebook, Twitter, Google+, Linkedin, MySpace, etc.) are used as media providing their users with opportunities to communicate and socialize with each other through facilities such as e-mail, instant messaging, video and photograph sharing.

This rapid increase in the use of social networking sites has brought about positive results such as communication, interaction, sharing, collaboration and socialization for individuals, while at the same time has led to problematic and pathological results such as reduction in face-to-face communication (7). 
The period in which friendship relations and the impression on friendship groups gain importance is the period of adolescence (10). University years are the last years of adolescence. University life is an environment that creates stress and anxiety for young people.

The young person faces a responsibility to make personal decisions on many issues such as where and what to do, which social groups he/she will enter and when and where to get help (1). During university years, young people are ready to establish social and intimate relations. However, if the social anxiety of the young person is high, he/she will be faced with the threat of being alone and will try to avoid intimate relations. It can be said that their families and their girlfriend /boyfriend with whom they have intimate relations are the most important source of social support for young people (4).

Sternberg (8) defines the romantic relationship as a passionate intimacy between man and woman that includes psychological, emotional and sexual attachment. A very important part of human life is made up of intimate relations. Romantic relations considered among the intimate relations are of different character from other types of relations (friendship, family relations etc.) and have a different meaning for each individual. In other words, perceptions, attitudes and behaviours related to romantic relation are specific to the individual (4).

Different individuals may experience different feelings in their relations depending on their age, appearance, height, weight, eye colour, physical disorders, behaviours, professional success, attitudes, opinions, intelligence, cognitive confusion, verbal skills, education level, social and economic class, family background, the number and gender of siblings, feelings towards the family, the quality of the parents' marriage, race and ethnic group, social and political connections, acceptance of gender roles, physical and emotional health, emotional maturity, level of neuroticism, degree of alienation to the family, pessimism, predisposition towards depression, tendency to tell lies and to display conflicting behaviours and substance abuse. Accordingly, partner selection provides important information for understanding the differences between individuals' romantic interests and their harmony (4).

The anxiety of interaction, also known as social anxiety, is defined by the American Psychiatric Association as the fear constantly arising when the individual needs to communicate with individuals whom he/she does not know. The individual's happiness and confidence in 
his/her life rely on his/her establishing successful intimate relations with others. According to Sternberg (8), intimacy includes being connected to the emotionally loved person in mutual understanding and communication. The quality of the intimate relations established influences the personal and social adjustment of individuals, supports their cognitive development, and increases their self-esteem and success (4).

\section{PURPOSE}

The purpose of the current study is to investigate the relationships between the perceived social support, interaction anxiousness, gender, relationship status and purposes for using the social networking sites of the female and male students from the School of Physical Education and Sports in Aydın Adnan Menderes University and the Faculty of Sports Sciences in Muğla Sitkı Koçman University.

\section{METHOD}

The study group of the current research is comprised of 104 female (61.9\%) and 117 male (61.3\%) students attending the School of Physical Education and Sports in Aydin Adnan Menderes University and 64 female $(38.1 \%)$ and 74 male $(38.7 \%)$ students attending the Faculty of Sports Sciences in Muğla S1tkı Koçman University; a total of 359 students, in 20152016 academic year (Table1).As the data collection tools, the "Multidimensional Scale of Perceived Social Support" and the "Interaction anxiousness Scale" were used.

\section{Table 1. Frequency Distribution of the Number and Gender of the Participating} Students

\begin{tabular}{lccc}
\hline \multirow{2}{*}{ Universities } & \multicolumn{3}{c}{ Gender } \\
& Female & Male & Total \\
\cline { 2 - 4 } & $\mathbf{n}$ & $\mathbf{n}$ & $\mathbf{n}$ \\
\hline Aydın Adnan Menderes University & 104 & 117 & 221 \\
Muğla Sitkı Koçman University & 64 & 74 & 138 \\
\hline Total & $\mathbf{1 6 8}$ & $\mathbf{1 9 1}$ & $\mathbf{3 5 9}$ \\
\hline
\end{tabular}


The Multidimensional Scale of Perceived Social Support (MSPSS) was developed by Zimmet et al. in 1988 and adapted to Turkish by Eker et al. (3).The Multidimensional Scale of Perceived Support (MSPSS) is a self-report scale to measure the social support coming from three different sources (friend, family and special person) and the adequacy of the source. The scale can measure the perceived social support in three sub-dimensions that are family, friends and important others. The scale consists of 12 items. In the scale, there are four items for each sub-dimension; family (Items 3, 4, 8, 11), friends (Items 6, 7, 9, 12) and special person (Items 1, $2,5,10)$. Each item is in the form of 7-point Likert scale with the following response options; "Very Strongly Agree (7 points)", 'Strongly Agree (6 points)", "Mildly Agree (5 points)", 'Neutral (4 points), 'Mildly Disagree (3

points)", "Strongly Disagree (2 points) and "Very Strongly Disagree (1 point).The lowest score to be taken from each sub-scale is 4 points and the highest score is 28 points. With the addition of the points taken from the four items in each sub-scale, the sub-scale total point is calculated and with the addition of the total points taken from the sub-scales, the total point for the whole scale is calculated. The lowest score to be taken from the whole scale is 12 points and the highest score is 84 points. A high score taken from the scale indicates that the perceived social support is high. In Eker et al. (3), the reliability coefficients of the sub-scales and the whole scale were found to be ranging from 0.80 to 0.95 .

The Interaction anxiousness Scale (IAS) was developed by Leary and Kowalski (6) and its reliability and validity studies in Turkish were made by Coşkun (2). IAS is a five-point 15item Likert-type scale comprehensively covering anxiety-inducing settings such as interactions with strangers, someone in a position of authority, parties, casual get-togethers, interactions with the opposite sex, job interviews and other undefined interactions. The results of different factor analyses conducted show that the items in the scale are gathered under a single factor as in the original scale and explain $44 \%$ of the total variance. The Cronbach alpha coefficient calculated for the internal consistency of the scale is 0.91 and the test-retest reliability coefficient obtained in applications conducted in a three-week interval is 0.80 . High scores taken from the scale indicate increasing social interaction anxiousness. In both of the universities, the scales were administered to the participating students in the classroom environment. It took 10-15 minutes to complete each scale. The scale items were accepted to 
have been responded by the participating students sincerely and willingly. Since the number of observations was more than 70, Kolmogorov Smirnov test was used to test whether the data was normally distributed. Kolmogorov-Smirnov test values for scale items were calculated as Z $=0.714$ and $p=0.658$. Parametric tests were used in statistical analysis since it was understood that the data showed normal distribution and that parametric test assumptions were provided. The significance of the difference between the average for two groups independent of a continuous variable indicated by the measurement was determined by the Independent Sample $\mathrm{T}$ test. The significance of averages for three or more independent groups was tested with One Way Anova, Independent K Sample Tests. The Tukey test was used to determine which groups the difference between the independent groups was, as the groups were

homogenously distributed. Chi-squre test was used to compare independent groups of qualitatively specified data. In the evaluation of the correlations between the variables used in the current study, Pearson

correlation coefficient was used (r). Frequency distribution of the participants across their school, faculty and gender was determined. The statistical analyses of the collected data were performed in SPSS 22.0 program package in 95\% confidence interval and at the error levels of 0.05 .

\section{FINDINGS}

The study group of the current research is comprised of a total of 359 students (168 females and 191 males) attending the School of Physical Education and Sports in Aydın Adnan Menderes University and Faculty of Sports Sciences in Muğla Sttkı Koçman University (Table 1). As the data collection tools, the "Multidimensional Scale of Perceived Social Support" and the "Interaction anxiousness Scale" were used. 
Table 2. Results of t-test Conducted to Determine Whether the Students' Perceived Social Support and Interaction Anxiousness Vary Significantly Depending on Gender

\begin{tabular}{lccccccc}
\hline \multirow{2}{*}{ Variables } & Gender & $\mathbf{n}$ & $\overline{\mathbf{X}}$ & $\mathbf{S d} \pm$ & \multicolumn{2}{c}{$\mathbf{t ~ T e s t}$} \\
\hline \multirow{2}{*}{ Perceived social support } & Female & 168 & 63.15 & 15.7 & 0.150 & 0.881 \\
& Male & 191 & 62.92 & 14.4 & & \\
\cline { 3 - 7 } Interaction anxiousness & Female & 168 & 39.51 & 8.37 & -0.140 & 0.889 \\
& Male & 191 & 39.62 & 7.45 & & \\
\hline
\end{tabular}

As can be seen in Table 2, the students' perceived social support and interaction anxiousness do not vary significantly depending on gender ( $p>0.05)$. Thus, it can be argued that gender does not affect the perceived social support and interaction anxiousness.

\begin{tabular}{|c|c|c|c|c|c|c|}
\hline \multicolumn{7}{|c|}{$\begin{array}{l}\text { Table 3. Results of the t-test Conducted to Determine Whether the Students' } \\
\text { Perceived Social Support and Interaction Anxiousness Vary Significantly Depending } \\
\text { on the Relationship Status }\end{array}$} \\
\hline \multirow{2}{*}{ Variables } & \multirow{2}{*}{$\begin{array}{l}\text { Is there a } \\
\text { relationship? }\end{array}$} & \multirow{2}{*}{$\mathbf{n}$} & \multirow{2}{*}{$\overline{\mathbf{X}}$} & \multirow{2}{*}{$\mathbf{S d} \pm$} & \multicolumn{2}{|c|}{ t Test } \\
\hline & & & & & $\mathbf{t}$ & $\mathbf{p}$ \\
\hline \multirow{2}{*}{ Perceived Social Support } & Yes & 184 & 65.96 & 16.22 & 3.886 & $0.000 *$ \\
\hline & No & 175 & 59.95 & 12.95 & & \\
\hline \multirow{2}{*}{ Interaction anxiousness } & Yes & 184 & 38.99 & 8.37 & -1.414 & 0.158 \\
\hline & No & 175 & 40.17 & 7.32 & & \\
\hline
\end{tabular}

* 0.05 significance level

As can be seen in Table 3, while there is a statistically significant difference between the perceived social support of the students having a relationship and that of the students not having a relationship $(\mathrm{p}=0.000)$, there is no significant difference between these two groups of students in terms of their interaction anxiousness ( $>>0.05)$. In light of these findings, it can be argued that the perceived social support of the students having a relationship is higher and that the students' relationship status does not affect their interaction anxiousness. 
Table 4. The Correlation between the Perceived Social Support and Interaction Anxiousness

\begin{tabular}{lccc}
\hline \multirow{2}{*}{ Variables } & \multicolumn{3}{c}{ Interaction anxiousness } \\
\cline { 2 - 4 } & $\mathbf{n}$ & $\mathbf{r}$ & $\mathbf{p}$ \\
\hline Perceived social support & 359 & $-0.278^{* *}$ & 0.000 \\
\hline
\end{tabular}

**0.01 significant (bidirectional)

As can be seen in Table 4, there is a low and negative correlation between the students' perceived social support and interaction anxiousness $(r=-0.278)$. Thus, it can be said that with the students' increasing level of perceived social support, their interaction anxiousness decreases. In other words, as the social support perceived by students increases, their interaction anxiousness decreases.

\begin{tabular}{|c|c|c|c|c|c|c|}
\hline \multicolumn{7}{|c|}{$\begin{array}{l}\text { Table 5. The Relationship between } \\
\text { Networking Sites and Their Gender }\end{array}$} \\
\hline \multirow{2}{*}{$\begin{array}{l}\text { Purpose for using the social } \\
\text { networking sites }\end{array}$} & \multicolumn{3}{|c|}{ Gender } & \multirow{2}{*}{$\mathbf{X}^{2}$} & \multirow{2}{*}{ df } & \multirow{2}{*}{$\mathbf{p}$} \\
\hline & Female & Male & Total & & & \\
\hline Interacting with friends & 89 & 75 & 164 & 32.113 & 5 & $0.000 *$ \\
\hline Interacting with the family & 26 & 19 & 45 & & & \\
\hline Meeting with new people & 5 & 36 & 41 & & & \\
\hline Playing games & 5 & 10 & 15 & & & \\
\hline Watching videos & 11 & 25 & 36 & & & \\
\hline Status update & 32 & 26 & 58 & & & \\
\hline Total & 168 & 191 & 359 & & & \\
\hline
\end{tabular}

* 0.05 significance level

As can be seen in Table 5, there is significant difference stemming from gender between the students' reasons for using social networking sites $(\mathrm{p}<0.05)$. While the female students use the social networking sites more for "interacting with friends and families" and "status update", the male students use them more for "meeting with new people" and" playing games". 
Table 6. The Relationship between the Students' Reasons for Using the Social Networking Sites and Their Perceived Social Support

\begin{tabular}{lcccccc}
\hline \multirow{2}{*}{$\begin{array}{l}\text { Purpose for using the social } \\
\text { networking sites }\end{array}$} & $\mathbf{n}$ & $\overline{\mathbf{X}}$ & $\mathbf{S d} \pm$ & $\mathbf{F}$ & $\mathbf{p}$ & Difference \\
\hline Interacting with friends & 164 & 64.41 & 15.63 & 2.662 & $0.022 *$ & $1-3$ \\
Interacting with the family & 45 & 64.82 & 15.25 & & & $3-5$ \\
Meeting with new people & 41 & 70.12 & 12.89 & & & \\
Playing games & 15 & 62.93 & 9.63 & & & \\
Watching videos & 36 & 60.17 & 14.36 & & & \\
Status update & 58 & 62.98 & 14.76 & & & \\
\hline
\end{tabular}

*0.05 significance level

As can be seen in Table 6, there is a significant relationship between the students' perceived social support and their purposes of using the social networking sites $(\mathrm{p}<0.05)$. Thus, the students' purposes for using the social networking sites affect their perceived social support. The perceived social support of the students using the social networking sites for "meeting with new people" is significantly higher than that of the students using them for "interacting with friends" and "playing games".

Table 7. The Relationship between the Students' Purpose for Using the Social Networking Sites and Their Interaction Anxiousness

\begin{tabular}{lccccc}
\hline \multirow{2}{*}{ Purpose for using the social networking sites } & \multicolumn{5}{c}{ Interaction anxiousness } \\
\cline { 2 - 6 } & $\mathbf{n}$ & $\overline{\mathbf{X}}$ & $\mathbf{S d} \pm$ & $\mathbf{F}$ & $\mathbf{p}$ \\
\hline Interacting with friends & 164 & 39.4 & 7.46 & 0.897 & 0.483 \\
Interacting with the family & 45 & 38.62 & 6.37 & & \\
Meeting with new people & 41 & 38.63 & 7.26 & & \\
Playing games & 15 & 38.6 & 6.63 & & \\
Watching videos & 36 & 41.5 & 8.44 & & \\
Status update & 58 & 40.5 & 10.1 & & \\
\hline
\end{tabular}

As can be seen in Table 7, there is no significant relationship between the students'

reasons for using the social networking sites and interaction anxiousness $(p>0.05)$. Thus, it can be said that the students' purposes for using the social networking sites do not affect their interaction anxiousness. 
Table 8. Correlation between the Interaction Anxiousness and Some Variables

\begin{tabular}{lccc}
\hline \multirow{2}{*}{ Variables } & \multicolumn{3}{c}{ Interaction anxiousness } \\
\cline { 2 - 4 } & $\mathbf{n}$ & $\mathbf{r}$ & $\mathbf{p}$ \\
\hline Perceived social support & 359 & $-0.278^{* *}$ & 0.000 \\
Purposes for using the social networking sites & 359 & 0.070 & 0.0183 \\
Relationship status & 359 & 0.075 & 0.0158 \\
\hline
\end{tabular}

**0.01 significance level (bidirectional)

As can be seen in Table 8, there is a negative and low correlation between the students' perceived social support and their interaction anxiousness $(\mathrm{r}=-0.278)$. There is no correlation between the students' purposes for using the social networking sites, relationship status and interaction anxiousness. Thus, it can be argued that with the students' increasing perceived social support, their interaction anxiousness decreases.

Table 9. Correlation between the Perceived Social Support and Some Variables

\section{Variables}

Interaction anxiousness
Relationship status
Purposes for using the social networking sites

\section{Perceived social support}

\begin{tabular}{ccc}
\hline $\mathbf{n}$ & $\mathbf{r}$ & $\mathbf{p}$ \\
359 & $-0.278 * *$ & 0.000 \\
359 & $-0.200 * *$ & 0.000 \\
359 & 0.022 & 0.673 \\
\hline
\end{tabular}

As can be seen in Table 9, there is a negative, low and significant correlation between the perceived social support and interaction anxiousness and between the perceived social support and the relationship status ( $\mathrm{r}=-0.278$ and $\mathrm{r}=-0.200$, respectively). There is no correlation between the purposes for using the social networking sites and the perceived social support ( $\mathrm{p}>0.05)$. Thus, it can be argued that with the students' increasing perceived social support, their interaction anxiousness decreases and that the students' relationship status affects their perceived social support. It is seen that the perceived social support of the students not having a relationship is relatively lower. On the other hand, the students' purposes for using the social networking sites do not affect their interaction anxiousness. 


\section{DISCUSSION AND CONCLUSION}

In the current study, it was found that the participating students' perceived social support and interaction anxiousness does not vary depending on gender. Thus, it seems that gender does not affect the perceived social support and interaction anxiousness.

Leary and Kowalski (5) investigated the conflicting results related to gender in the literature and it was concluded that such conflicting results are not surprising. Males and females socialize as equipped with different social abilities and thus they may create different images. Therefore, social anxiety experienced by males and females depends on the reactions they receive from the society in which they live and their self-presentation (9).

A negative, low and significant correlation was found between the participating students' perceived social support and interaction anxiousness. Thus, it can be said that with the students' increasing perceived social support, their interaction anxiousness decreases.

While a significant difference was found between the perceived social support of the students having a relationship and that of the students not having a relationship, no such difference was found for interaction anxiousness. In light of this finding, it can be argued that the perceived social support of the students having a relationship is relatively higher; yet, the students' relationship status does not affect their interaction anxiousness. Yet, though there are some positive sides of communication over the social networking sites, this medium of communication is less threatening; thus, more preferable for some people than face-to-face communication, which may lead to some adversities in the life of the individual.

In the current study, it was found that while the female students mostly use the

social networking sites for purposes such as "interacting with friends", "interacting with the family" and "status update", the male students mostly use them for "meeting with new people" and "playing games".

The students' purposes for using the social networking sites affect their perceived social support. In this connection, the perceived social support of the students using the social 
networking sites for "meeting with new people" is higher than that of the students using it for "interacting with friends" and "playing games".

A negative and low correlation was found between the students' perceived social support and interaction anxiousness. However, no correlation was found between the purposes for using the social networking sites, relationship status and interaction anxiousness. This finding indicates that with the students' increasing perceived social support, their interaction anxiousness decreases. The significant correlation found between the purposes for using social networking sites and their perceived social support indicates that the students' purposes for using the social networking sites affect their perceived social support.

The perceived social support of the students having a relationship was found to be higher than that of the students not having a relationship. On the other hand the relationship status does not affect interaction anxiousness. This finding concurs with the literature reporting that the perceived social support of the students having a relationship is higher than that of the students not having a relationship (10).

\section{REFERENCES}

1. Aksüllü N, Doğan S. (2004).Huzurevinde ve evde yaşayan yaşlılarda algılanan sosyal destek etkenleri ile depresyon arasındaki ilişki. Anadolu Psikiyatri Dergisi, 5(2): 76-84.

2. Coşkun H. (2009).Etkileşim kaygısı ölçeği, geçerlik ve güvenilirlik çalışması. Türk Psikoloji Yazıları, 12(23):41-49.

3. Eker D, Arkar H, Yaldız H. (2001). Çok boyutlu algılanan sosyal destek ölçeğinin gözden geçirilmiş formunun faktör yapısı, geçerlilik ve güvenirliği. Türk Psikiyatri Dergisi, 12(1):17-25.

4. Küçükarslan M. (2011). Mersin üniversitesi öğrencilerinin romantik ilişkilere yönelik inançlarının cinsiyet, sınıf düzeyi ve romantik ilişki yaşama durumu değişkenlerine göre incelenmesi. Yayınlanmamış yüksek lisans tezi. Mersin Üniversitesi Eğitim Bilimleri Enstitüsü, Mersin.

5. Leary M, Kowalski NR. (1995). Social Anxiety. New York:The Guilford Press. 
6. Leary MR, Kowalski RM. (1993). The interaction anxiousness scale: Construct and criterion-related validity. Journal of Personality Assessment, 61(1):136-146.

7. Özgür H. (2013). Öğretmen adaylarının sosyal ağ bağımlılı̆̆ı, etkileşim kaygısı ve yalnızlık düzeyi arasındaki ilişkinin incelenmesi. International Journal of Human Sciences, 10(2): 667-690.

8. Sternberg RJ. (1986). A triangular theory of love. Psychological Review, 93(2): 119135.

9. Sübaşı G. (2010). Üniversite öğrencilerinde sosyal kaygıyı yordayıcı bazı değişkenler. 32(144):3-15.

10. Şahin H, İşleyen F, Özdemir S. (2012). Eğitim fakültesi öğrencilerinin romantik ilişki durumları ve sosyal ağ kullanımlarına göre etkileşim kaygısı ve sosyal destek algılarının incelenmesi. Mersin Üniversitesi Eğitim Fakültesi Dergisi, 8(2): 25-36. 